\title{
Analisis Pola Asuh Orang Tua Terhadap Prestasi Siswa Kelas V SD
}

\author{
Titin Rohana ${ }^{1 *}$, Qoriati Mushafanah², Intan Rahmawati ${ }^{3}$ iD \\ 1,2,3 Program Studi Pendidikan Guru Sekolah Dasar, Fakultas Ilmu Pendidikan Universitas PGRI Semarang, Indonesia \\ *Corresponding author: rohana@gmail.com
}

\begin{abstract}
Abstrak
Pola asuh orang tua yang berbeda-beda terhadap anaknya maka akan berdampak terhadap prestasi siswa di sekolah. Penelitian ini bertujuan untuk mengetahui hubungan pola asuh orang tua terhadap prestasi siswa kelas V SD. Jenis Penelitian ini adalah kualitatif. Sampel dalam penelitian ini adalah siswa, orang tua siswa dan guru kelas V. Teknik analisis data yang digunakan adalah analisis deskriptif. Hasil penelitian menunjukan bahwa terdapat pola asuh yang berbeda-beda yang diterapkan orang tua. Metode pengumpulan data yang digunakan yaitu observasi, wawancara, angket dan dokumentasi. Pola asuh demokratis lebih banyak diterapkan oleh orang tua, menyusul pola asuh permisif dan otoriter. Hasil dari penelitian ini adalah siswa dengan pola asuh demokratis dan otoriter mempuyai prestasi belajar yang sangat baik dan baik. Sedangkan siswa dengan pola asuh permisif mempunyai prestasi belajar yang kurang. Berdasarkan penelitian. dapat disimpulkan bahwa terdapat hubungan yang baik antara pola asuh orang tua dengan prestasi siswa.
\end{abstract}

Kata kunci: Pola asuh orang tua, prestasi belajar siswa

Abstract

This study aims to determine the relationship between parenting and student achievement in 5th grade SD Negeri Jomblang 02 Semarang. This type of research is qualitative research. The samples in this study were students, parents, and teachers of 5 th elementary grades. Data collection methods used were observation, interviews, questionnaires, and documentation. The data analysis technique used is descriptive analysis. The results showed that there were different parenting patterns applied by parents. More democratic parenting is applied by parents, following permissive and authoritarian parenting styles. Parenting tends to be democratic as much as $61 \%$, parenting tends to be authoritarian by $31 \%$, and parenting tends to be permissive at $8 \%$. The results of learning achievement show that 6\% of students have very good achievements, 69\% of students have good achievements, and $25 \%$ of students have fairly good achievements. Students with democratic and authoritarian parenting patterns have excellent and good learning achievements. Meanwhile, students with permissive parenting have less learning achievement. Based on research. It can be concluded that there is a goodrelationship between parenting styles and student achievement.

Keywords: Parenting styles, student learning achivement

\section{Introduction}

'Pendidikan dipandang sebagai proses yang sangat bermanfaat bagi kehidupan yang dapat digunakan sebagai persiapan untuk melanjutkan kejenjang yang lebih tinggi, selain itu pendidikan memegang peranan penting dalam mempersiapkan sumber daya manusia yang berkualitas (Rahmawati et al., 2014; Romdhani, 2016). Pendidikan adalah usaha yang dilakukan dengan sengaja dan bertujuan untuk meningkatkan pengetahuan, keterampilan, serta sikap anak didik (ANDRIYANI, 2013). Maka pendidikan hendaknya dikelola, baik secara kualitas maupun kuantitas. Hal ini bisa tercapai apabila pembelajar dapat menyelesaikan pendidikan tepat pada waktunya dengan hasil belajar yang baik. Pendidikan harus mampu meningkatkan sumber daya manusia dan mengimbangi kemajuan IPTEK yang

$\begin{array}{lll}\text { History: } & & \text { Publisher: Undiksha Press } \\ \text { Received } & : 24 \text { August } 2020 & \text { Licensed: This work is licensed under } \\ \text { Revised } & : \text { 1 September } 2020 & \text { a Creative Commons Attribution } 3.0 \text { License } \\ \text { Accepted } & : \text { :24 September } 2020 & \end{array}$


semakin pesat. Jika tidak dapat mengimbangi IPTEK, maka akan tertinggal dan terlupakan. Untuk meningkatkan kualitas sumber daya manusia memiliki upaya yang salah satunya adalah peningkatan kualitas pendidikan. Indrawati (2015) mengungkapkan bahwa "prestasi belajar merupakan hasil perubahan tingkah laku yang meliputi ranah kognitif, afektif, dan psikomotor". Maka dapat diasumsikan prestasi belajar tidak akan pernah dihasilkan selama seseorang tidak melakukan suatu kegiatan yang menjurus dengan adanya perubahan tingkah laku. Prestasi belajar tidak dapat dipisahkan dari proses belajar yang dijalani oleh seorang siswa dalam dunia pendidikan. Tinggi rendahnya hasil belajar siswa dipengaruhi oleh keberhasilan belajarnya yang dipengaruhi oleh faktor internal dan eksternal. DWI WAHYUDI (2016) menyatakan secara global banyak faktor - faktor yang mempengaruhi prestasi belajar siswa dibedakan menjadi tiga macam, yakni: Faktor internal (faktor dari dalam siswa), yakni keadaan/kondisi jasmani dan rohani siswa. Faktor eksternal (faktor dari luar siswa), yakni kondisi lingkungan disekitar siswa. Dan Faktor pendekatan belajar, yakni jenis upaya belajar siswa yang meliputi strategi dan metode yang digunakan siswa untuk melakukan kegiatan pembelajaran materi - materi pelajaran.

Berdasarkan faktor-faktor di atas maka faktor keluarga merupakan faktor yang paling penting, dikarenakan keluarga adalah lingkungan pendidikan pertama bagi anak, yang berperan penting dalam membentuk pola kepribadian anak . Keluarga merupakan lembaga pendidikan tertua, yang bersifat informal. Ayah dan ibu di dalam keluarga sebagai pendidiknya, dan anak sebagai terdidiknya. Keluarga sangat berpengaruh terhadap keberhasilan anak dalam menempuh pendidikannya di sekolah, sehingga sangat mempengaruhi prestasi belajar anak pada jenjang pendidikan yang sedang ditempuhnya(Romdhani, 2016; Shaleh, 2016; Soraya \& Khafid, 2016). Seperti yang telah diungkapkan di atas, pola asuh keluarga termasuk ke dalam salah satu faktor di luar individu (faktor sosial) yang dapat mempengaruhi pencapaian hasil belajar seorang siswa. Penelitian yang dilakukan oleh Yusniah (dalam Rahmawati, 2014) menunjukkan fakta bahwa pola asuh orang tua memegang peranan penting dalam perkembangan belajar anak dan sangat besar pengaruhnya terhadap tinggi rendahnya pencapaian prestasi belajar anak di sekolah. Pola asuh sendiri merupakan pola yang bersifat konsisten dari waktu ke waktu, pola perilaku ini dapat di rasakan oleh anak dan bisa memberi efek negatif maupun positif (Aminudin, 2016; Vidya \& Mustikasari, 2018). Orang tua sebagai pendidikan utama memiliki pola tersendiri dalam mengasuh dan membimbing anak. Pola asuh yang ditanamkan tiap keluarga berbeda, hal ini tergantung pandangan dari tiap orang tua (Rabiatul, 2017). Pola asuh orang tua yang baik mampu meningkatkan prestasi belajar anak. Dalam pengertian psikologis, keluarga adalah sekumpulan orang yang hidup bersama dalam tempat tinggal yang sama dan masingmasing anggota merasakan adanya pertautan batin sehingga terjadi saling mempengaruhi, saling memperhatikan, dan saling menyerahkan diri. Dalam berbagai dimensi dan pengertia keluarga tersebut, esensi keluarga (ibu dan ayah) adalah kesaturahan dan kesatutujuan atau keutuhan dalam mengupayakan anak untuk memiliki dan mengembangkan disiplin diri. (Shochib, 2010:17).

Orang tua merupakan pendidikan pertama untuk anak-anak mereka, setelah itu baru sekolah dan lingkungan disekitarnya. Hal ini dipertegas pernyataan bahwa Keluarga sebagai lingkungan belajar pertama sebelum lingkungan sekolah dan masyarakat (Wahid et al., 2020). Pendidikan lingkungan keluarga berlangsung sejak anak lahir. Bahkan setelah dewasa pun orang tua masih berhak memberikan nasihat kepada anak. Oleh karena itu peran orang tua sangat strategis dalam pendidikna nilai kepada anak. Pola asuh orang tua yang diterima anak sangat beragam, hal itu tergantung dari cara pola asuh keluarga yang diterapkan kepada anaknya. Ada lima belas tipe pola asuh orang tua yang ada dalam keluarga, yaitu (1) Gaya Otoriter, (2) Gaya Demokratis , (3) Gaya Laissez-Faire, (4) Gaya Fathernalistik, (5) Gaya Karismatik, (6) Gaya Melebur Diri, (7) Gaya Pelopor, (8) Gaya Manipulasi, (9) Gaya 
Transaksi, (10) Gaya Biar Lambat Asal Selamat, (11) Gaya Alih Peran, (12) Gaya Pamrih, (13) Gaya Tanpa Pamrih, (14) Gaya Konsultan, (15) Gaya Militeristik. Pola asuh keluarga secara tidak langsung berbeda-beda dan mempengaruhi kebiasaan-kebiasaan anak, baik di rumah maupun di sekolah. Orang tua yang membiasakan anak untuk selalu belajar di rumah akan berpengaruh terhadap hasil belajar anak yang bersangkutan di sekolah. Kebiasaan belajar berhubungan positif dengan prestasi belajar, yaitu semakin baik kebiasaan belajar siswa akan semakin baik nilai prestasi belajarnya. Kebiasaan belajar merupakan cara bertindak yang diperoleh melalui belajar berulang-ulang yang pada akhirnya menjadi menetap dan bersifat otomatis (MUSTOFA, 2020). Kebanyakan siswa hanya belajar pada saat akan ada ulangan dan ujian saja, sehingga kadang-kadang hasilnya jauh dari yang diharapkan, bahkan pelajaran yang dipelajari dalam waktu semalam akan kurang bertahan dalam ingatan dibandingkan jika dipelajari dengan lebih sering dalam bertahap. Untuk menghadapi persoalan tersebut, kebiasaan belajar siswa perlu dikembangkan sedikit demi sedikit demi tercapainya prestasi belajar yang optimal.

Bukti kuat juga ditemukan ketika peneliti melakukan magang 3 kurang lebih 50 hari dan wawancara pada tanggal 07 november 2019 tehadap guru kelas V SD Negeri Jomblang 02 Semarang ditemukan berbagai fakta yang dapat mempengaruhi prestasi siswa. Fakta berupa pola asuh orang tua yang berbeda-beda terhadap anaknya maka akan berdampak terhadap prestasi siswa di sekolah. Seperti yang dikatakan oleh guru kelas V SD Negeri Jomblang 02 Semarang bahwa ada orang tua yang peduli terhadap prestasi siswa dan ada sebagian orang tua yang kurang peduli terhadap prestasi siswa. Orang tua yang peduli terhadap prestasi siswa dilihat dari cara orang tua menyediakan fasilitas atau kebutuhan anak di sekolah seperti membelikan buku LKS, membelikan seragam anak dan kehadiran orang tua di sekolah, sedangkan orang tua yang kurang peduli terhadap prestasi siswa dilihat dari cara orang tua yang mengabaikan anak seperti tidak membelikan buku LKS, tidak hadir saat pengambilan rapot, tidak menandatangani rapot, dan orang tua yang bekerja di luar kota bahkan orang tua yang broken home sehingga anak dititipkan untuk tinggal bersama nenek atau saudaranya. Berdasarkan kasus ini, maka kepedulian dan perhatian orang tua memiliki dampak pada perkembangan anak dan prestasi anak.

Berdasarkan realitas tersebut, maka penting dilakukan analisis pola asuh orang tua terhadap anaknya untuk meningkatkan prestasi belajar mereka, peneliti tertarik mengangkat Tujuan menganalisis Pola Asuh Orang Tua Terhadap Prestasi Siswa Kelas V Sd Negeri Jomblang 02 Semarang". Penelitian ini di harapkan mampu menggali lebih dalam tentang hubungan antara pola asuh orang tua terhadap hasil belajar siswa kelas V semester ganjil SD Negeri Jomblang 02 Semarang.

\section{Materials and Methods}

Penelitian ini dilakukan dengan pendekatan kualitatif dengan menggunakan pendekatan deskriptif peresentase. Peneliti mendeskripsikan pengaruh pola asuh orang tua terhdap prestasi suswa kelas V SD Negeri Jomblang 02 Semarang dalam bentuk naratif dan keadaan yang sesungguhnya. Penelitian kualitatif merupakan temuan baru yang sebelumnya belum pernah ada. Temuan dapat berupa deskripsi atau gambaran suatu obyek yang sebelumnya masih remang-remang atau gelap sehingga setelah diteliti menjadi jelas, dapat berupa hubungan kausal dan interaktif, hipotesis atau teori.

Teknik yang digunakan adalah analisis deskriptif untuk menjelaskan peran dan pola asuh orang tua yang diterapkan terhadap prestasi siswa. Tujuannya adalah untuk mendeskripsikan peran dan pola asuh orang tua terhadap prestasi siwa kelas V SD Negeri Jomblang 02 Semarang.

Sampel dalam penelitian ini sebanyak 36 siswa kelas $\mathrm{V}$ beserta orang tuanya dan guru kelas $\mathrm{V}$. Teknik pengumpulan data dengan menggunakan obervasi, wawancara, angket dan 
dokumentasi. Pada penelitian ini observasi dilakukan secara tersetruktur yang merupakan observasi yang sudah dirancang secara sistematis tentang apa yang akan diamati, kapan, dan dimana tempatnya. Wawancara terstruktur kepada guru kelas dan orang tua siswa kelas $\mathrm{V}$ terkait dengan pola asuh orang tua terhadap siswa. Kuesioner atau angket berupa pernyataanpernyataan yang harus dijawab oleh siswa dan orang tua siswa kelas V sebagai responden.

Metode analisis data yang digunakan dalam penelitian ini (Mursidik et al., 2015) yaitu:

a) Reduksi data yaitu merangkum dan memilih hal-hal yang pokok kemudian memfokuskan pada hal-hal yang penting untuk mencari tema atau polanya. Dalam penelitian ini, peneliti memproduksi data yang akan menerangkan pola asuh orang tua terhadap prestasi siswa kelas V SD Negeri Jomblang 02 Semarang. Data yang telah direduksi akan memberikan gambaran jelas dan akan mempermudah peneliti untuk mengumpulkan data. b) Data Display adalah cara yang dilakukan untuk memudahkan untuk memahami data-data. Dalam penelitian kualitatif, yang paling sering adalah dengan teks yang bersifat naratif. Akan tetapi bisa dalam bentuk uraian singkat, bagan dan sejenisnya. Dalam penelitian menyajikan data dalam bentuk uraian singkat. Uraian ini menunjukkan hasil dari pola asuh orang tua terhadap prestasi siswa kelas V SD Negeri Jomblang 02 Semarang. c) Conclusion draig/ verification, setelah disajikan langkah terakhir adalah penarikan kesimpulan dan verifikasi.

Teknik pemeriksaan data yang digunakan dalam penelitian ini adalah triangulasi. Triangulasi adalah teknik pemeriksaan keabsahan data yang memanfaatkan sesuatu yang lain. Pada penelitian teknik triangulasi yang digunakan yaitu triangulasi teknik, dimana data dapat diperoleh menggunakan wawancara, dokumentasi, observasi, dan angket. Sedangkan tringulasi sumber adalah pemeriksaan data yang diperoleh dari siswa, orang tua siswa dan guru kelas V SD Negeri Jomblang 02 Semarang.

\section{Results and Discussion}

\section{Hasil}

Penelitian ini menganalisis tentang pola asuh orang tua terhadap prestasi siswa. Penelitian ini dilakukan pada bulan juli 2020. Berdasarkan lima belas pola asuh peneliti menggunakan empat pola asuh orang tua yaitu pola asuh cenderung demokratis, pola asuh cenderung otoriter, pola asuh cenderung permisif dan pola asuh cenderung penelantaran. Setelah dilakukan penelitian, peneliti menemukan tiga pola asuh orang tua yang diterapkan di siswa kelas V SD Negeri Jomblang 02 Semarang yaitu pola asuh cenderung demokratis, pola asuh cenderung otoriter, dan pola asuh cenderung permisif sesuai dengan data yang diperoleh peneliti. Untuk mengetahui pola asuh orang tua peneliti menganalisis dengan menggunakan angket dan wawancara yang dibagikan secara online menggunakan google form kepada 36 siswa kelas $\mathrm{V}$ beserta orang tua siswa. Dalam data orang tua peneliti menemukan berbagai pekerjaan yang dimiliki orang tua berdasarkan presentase digambarkan pada Tebel 1.

Tabel 1. Pekerjaan Orang Tua

\begin{tabular}{clcc}
\hline No. & \multicolumn{1}{c}{ Pekerjaan Orang Tua } & Jumlah & Presentase \% \\
\hline 1. & Wiraswasta & 9 & 25 \\
2. & Buruh & 8 & 17 \\
3. & Ibu rumah tangga & 16 & 36 \\
4. & Pedagang & 3 & 8 \\
5. & Karyawan swasta & 2 & 5 \\
6. & Kayawan pabrik & 1 & 3 \\
7. & Sopir & 1 & 3 \\
8. & Tidak bekerja & 1 & 3 \\
\hline
\end{tabular}


Pendidikan orang tua memiliki pengaruh terhadap prestasi siwa seperti yang dikemukakan oleh (Pawestri, 2013) yang menyatakan bahwa tinggi rendahnya pendidikan orangtua, besar kecilnya penghasilan orangtua, serta rukun tidaknya orangtua dengan anakanaknya, tenang atau tidaknya situasi dalam rumah, semua itu turut mempengaruhi hasil belajar anak. Dalam kegiatan belajar di rumah, orang tua merupakan contoh terdekat dari anak-anaknya. Segala yang diperbuat orang tua tanpa di sadari akan ditiru oleh anakanaknya.

Dalam penelitian ini peneliti juga memperoleh data pendidikan orang tua yang dapat mempengaruhi prestasi siswa ditunjukkan pada Tabel 2.

Tabel 2. Pendidikan orang tua

\begin{tabular}{|c|c|c|c|}
\hline No. & Pendidikan Orang Tua & Jumlah & Presentase \% \\
\hline 1. & - & 5 & 14 \\
\hline 2. & SMP Sederajat & 10 & 27 \\
\hline 3. & SMA Sederajat & 18 & 50 \\
\hline 4. & Diploma & 1 & 3 \\
\hline 5. & DIII & 1 & 3 \\
\hline 6. & S1 & 1 & 3 \\
\hline
\end{tabular}

Berdasarkan hasil dari data angket dan wawancara yang telah di analisis dan di hitung, maka ditemukan berbagai pola asuh orang tua terhadap siswa yang disajikan dalam bentuk data dan disajikan pada Tabel 3.

Tabel 3. Hasil Presentase Jenis Pola Asuh Orang Tua

\begin{tabular}{clcc}
\hline No. & Pola asuh orang tua & Hasil Perolehan Siswa & Presentase \% \\
\hline 1. & Cenderung Demokratis & 22 & 61 \\
2. & Cenderung Otoriter & 11 & 31 \\
3. & Cenderung Permisif & 3 & 8 \\
4. & Cenderung Penelantaran & 0 & 0 \\
\hline
\end{tabular}

Berdasarkan hasil analisis ditemukan bahwa siswa yang mendapatkan pola asuh cenderung demokratis berjumlah 22 siswa dengan presentase $61 \%$, untuk siswa yang mendapatkan pola asuh cenderung otoriter berjumlah 11 siswa dengan presentase $31 \%$, sedangkan siswa yang mendapatkan pola asuh cenderung permisif berjumlah 3 siswa dengan presentase $8 \%$ dan untuk pola asuh cenderung penelantaran memiliki presentase $0 \%$ atau tidak ada karena memang tidak ada orang tua siswa yang menelantarkan anaknya atau orang tua yang tidak mementingkan kegiatan anak karena orangtua terlalu sibuk dengan urusan mereka sendiri.

Dari hasil analisis data yang telah dihitung terdapat pola asuh cenderung demoktratis yang paling banyak diterapkan oleh orang tua terhadap siswa dengan demikian bahwa pola asuh cenderung demokratis lebih dominan menyusul pola asuh cenderung otoriter dan pola asuh cenderung permisif. Penerapan pola asuh yang tepat untuk mendidik anak dapat mempengaruhi prestasi belajar anak dan tumbuh kembang anak kedepannya. Sehingga dalam proses pola asuh orang tua harus memperhatikan kebutuhan anak dan senantiasa memberikan perlindungan kepada anak. Berdasarkan perhitungan dari prestasi belajar siswa kelas V SD Negeri Jomblang 02 Semarang yang diperoleh dari rekap nilai ujian semester ganjil, mata pelajaran (Agama, Bahasa Indonesia, Matematika, IPA, IPS, SBdP, PJOK, Bahasa Jawa) pada Tabel 4. 
Tabel 4. Presentase Belajar Siswa Kelas V SDN Jomblang 02 Semarang

\begin{tabular}{lcc}
\hline \multicolumn{1}{c}{ Kategori Presentasi } & Jumlah Perolehan Siswa & Presentase (\%) \\
\hline Sangat Baik & 2 & 6 \\
Baik & 25 & 69 \\
Cukup Baik & 9 & 25 \\
Kurang & 0 & 0 \\
\hline
\end{tabular}

Berdasarkan hasil penelitian dapat diperoleh bahwa siswa yang mendapatkan prestasi Sangat Baik berjumlah 2 orang dengan presentase $6 \%$, siswa yang mendapatkan prestasi Baik berjumlah 25 orang dengan presentase $69 \%$, siswa yang mendapatkan prestasi Cukup Baik berjumlah 9 orang dengan presentase $25 \%$, sedangkan siswa yang mendapatkan prestasi kurang berjumlah 0 dengan presentase $0 \%$. Dalam pengkategorian belajar tersebut berdasarkan pada klasifikasi prestasi belajar menurut (Syah, 2011).

Terdapat pola asuh yang baik antara pola asuh orang tua dengan prestasi siswa, karena orang tua berusaha memberikan pola asuh yang baik kepada anak yang dapat membuat anak mempengaruhi prestasi anak yang baik di sekolah. Selain itu, ada beberapa faktor yang dapat mempengaruhi prestasi siswa seperti lingkungan sekolah, ruang lingkup kelas, dan intonasi guru saat menyampaikan materi kepada siswa. Orang tua memiliki berbagai pola asuh untuk mendidik, membimbing, dan menjaga anak. Pola asuh yang diterapkan orang tua akan mempengaruhi karakteritik anak dan prestasi anak pada kemudian hari. Sutratinah Tirtonegoro mengartikan prestasi belajar sebagai penilaian hasil usaha kegiatan belajar yang dinyatakan dalam bentuk simbol, angka, huruf, maupun kalimat yang dapat mencerminkan hasil yang sudah dicapai oleh setiap anak dalam periode tertentu. Prestasi belajar yang dimaksud ialah hasil (penguasaan) yang dicapai oleh siswa dalam bidang studi tertentu setelah mengikuti proses belajar mengajar. Prestasi siswa dapat diketahui melalui proses penilaian atau pengukuran melalui kegiatan evaluasi (U.S., 2012).

Berdasarkan hasil pola asuh orang tua dan prestasi belajar siswa maka untuk mempermudah peneliti memilih 5 siswa/siswi nilai dan rata-rata tertinggi berdasarkan rekap nilai ujian semester ganjil, mata pelajaran (Agama, Bahasa Indonesia, Matematika, IPA, IPS, SBdP, PJOK, Bahasa Jawa) yang ditentukan secara purposive dengan pola asuh orang tua dalam tabel 5 berikut.

Tabel 5. Prestasi Belajar Siswa Dengan Pola Asuh Orang Tua

\begin{tabular}{|c|c|c|c|c|}
\hline \multirow[b]{2}{*}{ Nama Siswa } & \multicolumn{2}{|c|}{ Prestasi Belajar } & \multirow[b]{2}{*}{$\begin{array}{c}\text { Nama Orang } \\
\text { Tua }\end{array}$} & \multirow[b]{2}{*}{$\begin{array}{c}\text { Pola Asuh } \\
\text { Orang Tua } \\
\end{array}$} \\
\hline & Nilai & Rata-rata & & \\
\hline $\begin{array}{l}\text { Devara Arantika Rafina } \\
\text { Ardo }\end{array}$ & 729 & 91 & $\begin{array}{l}\text { Wahyuni } \quad \text { Wiji } \\
\text { Hastuti }\end{array}$ & Demokratis \\
\hline Adrean Akhmal Siswanto & 722 & 90 & Endang Feriyanti & Demokratis \\
\hline Zahra Hendrawati & 695 & 87 & $\begin{array}{ll}\text { Hendro } & \text { Joko } \\
\text { Prasetyo } & \end{array}$ & Demokratis \\
\hline Devita Nissa Maharani & 694 & 86,75 & Gudela Purono & Otoriter \\
\hline Argani Jabbar Athaya & 689 & 86,12 & Tina Safitri & Demokratis \\
\hline
\end{tabular}

Berdasarkan kelima siswa-siswi yang mempunyai nilai tertinggi semua itu tidak terlepas dari pola asuh orang tua yang selalu mendidik dan membimbing anak supaya menjadi anak yang berprestasi. Pola asuh orang tua terhadap anak akan membentuk kepribadian diri anak baik dari segi kognitif, psikomotorik, dan afektif. Berdasarkan perhitungan dan analisis terhadap pola asuh orang tua dan prestasi belajar siswa yang 
diperoleh peneliti dari hasil wawancara dan angket yang diberikan melalui google form kepada orang tua kelas V SD Negeri Jomblang 02 Semarang sebagai berikut.

Pertama Devara Arantika Rafina Ardo meraih nilai tertinggi pertama dari nilai ujian semester ganjil mata pelajaran Agama, Bahasa Indonesia, Matematika, IPA, IPS, SBdP, PJOK, Bahasa Jawa yang keseluruhannya mendapatkan skor 729 dengan rata-rata 91. Dari hasil wawancara dan angket kepada Ibu Wahyuni Wiji Hastuti yang menerapkan pola asuh demokratis terhadap anak. Berdasarkan hasil wawancara didapatkan bahwa menghukum anak ketika anak belajar akan membuat anak tambah bandel, Ibu Wahyuni selalu mendampingi anak ketika belajar dan membebaskan anak tidak belajar saat libur sekolah, jika anak melakukan kesalahan tidak di hukum namun di tegur dan di nasihati, Ibu Wahyuni selalu mendukung dan berkerjasama dengan sekolah sepuya anak berprestasi.

Kedua Adrean Akhmal Siswanto meraih nilai tertinggi kedua dari nilai ujian semester ganjil mata pelajaran Agama, Bahasa Indonesia, Matematika, IPA, IPS, SBdP, PJOK, Bahasa Jawa yang keseluruhannya mendapatkan skor 722 dengan rata-rata 90. Dari hasil wawancara dan angket kepada Ibu Endang Feriyanti yang menerapkan pola asuh otoriter terhadap anak. Berdasarkan hasil wawancara didapatkan bahwa kadang-kadang Ibu Endang menghukum anak supaya mau belajar karena anak harus belajar setiap hari. Apabila anak tidak mematuhi aturan dalam keluarga anak di tegur dan kadang-kadang memberikan hukuman. Ibu Endang selalu mendukung memenuhi kebutuhan anak supaya berprestasi disekolah. Anak selalu diajarkan bahwa tidak ada perjanjian pada saat belajar karena yang terpenting anak selalu semangat dan memberikan pengertian yang baik tentang hidup yang baik.

Ketiga, Zahra Hendrawati meraih nilai tertinggi ketiga dari nilai ujian semester ganjil mata pelajaran Agama, Bahasa Indonesia, Matematika, IPA, IPS, SBdP, PJOK, Bahasa Jawa yang keseluruhannya mendapatkan skor 695 dengan rata-rata 87. Dari hasil wawancara dan angket kepada Bapak Hendro Joko Prasetyo yang menerapkan pola asuh demokratis terhadap anak. Berdasarkan hasi wawancara didapatkan bahwa Bapak Hendro tidak menghukum anak ketika anak tidak belajar karena menghukum anak tidak mendidik perkembangan jiwanya. Menemani anak belajar jika dalam kapasitas anak masih di bawah umur atau perlu bimbingan. Anak selalu di beri dukungan berupa semangat dan fasilitas yang layak. Jika anak melakukan kesalahan maka anak di tegur, orang tua bekerjsama supaya anak memperoleh prestasi di sekolah. Orang tua tidak melakukan perjanjian kepada anak pada saat belajar karena itu sama saja mengajari anak untuk berhitung untung rugi, anak dibiarkan berpikir bahwa belajar adalah kebutuhan.

Keempat, Devita Nissa Maharani meraih nilai tertinggi keempat dari nilai ujian semester ganjil mata pelajaran Agama, Bahasa Indonesia, Matematika, IPA, IPS, SBdP, PJOK, Bahasa Jawa yang keseluruhannya mendapatkan skor 694 dengan rata-rata 86,75. Dari hasil wawancara dan angket kepada Bapak Gudela Purono yang menerapkan pola asuh otoriter terhadap anak. Berdasarkan hasi wawancara didapatkan bahwa Bapak Gudela menghukum anak jika anak tidak belajar, mendampingi anak ketika beajar, anak harus selalu belajar setiap hari, memfasilitasi kebutuhan anak, menegur dan menasihati anak ketika tidak mematuhi aturan dalam keluarga, dan tidak pernah ada perjanjian saat belajar karena belajar adalah kewajiban seorang pelajar.

Kelima, Argani Jabbar Athaya meraih nilai tertinggi keempat dari nilai ujian semester ganjil mata pelajaran Agama, Bahasa Indonesia, Matematika, IPA, IPS, SBdP, PJOK, Bahasa Jawa yang keseluruhannya mendapatkan skor 689 dengan rata-rata 86,12. Dari hasil wawancara dan angket kepada Ibu Tina Safitri yang menerapkan pola asuh demokratis terhadap anak. Berdasarkan hasi wawancara didapatkan bahwa Ibu Tina tidak pernah menghukum anak ketika anak tidak belajar karena jika dimarahi atau dihukum akan mempengaruhi pola pikir anak dan lebih baik dinasihati secara perlahan supaya anak mau 
belajar. Selalu berusaha mendampingi anak belajar ketika di rumah dan tidak bekerja. Anak harus selalu belajar meski tidak ada tugas, selalu mendukung kegiatan anak di sekolah dengan memberikan izin latihan, jika anak tidak mematuhi aturan keluarga maka anak di tegur. Pada saat ank melanggar perjanjian anak tidak di hukum karena akan membuat anak takut dan tidak mau bercerita. Dalam pola asuh demokratis orang tua mendidik anak dengan penuh kasih sayang jika anak melakukan kesalahan maka anak akan di tegur bukan di hukum, orang tua selalu membimbing, mendidik anak dengan baik, dan memepersiapkan anak di masa depan. Sedangkan untuk pola asuh otoriter anak harus mengikuti kemauan orang tua, jika anak melakukan kesalahan maka anak akan di hukum.

\section{Pembahasan}

Berdasarkan hasil penelitian dan pembahasan pola asuh orang tua terhadap prestasi kelas V SD Negeri Jomblang 02 Semarang. Peneliti menemukan tiga pola asuh orang tua yang diterapkan di siswa kelas V SD negeri Jomblang 02 Semarang yaitu pola asuh cenderung demokratis, pola asuh cenderung otoriter, dan pola asuh cenderung permisif sesuai dengan data yang diperoleh peneliti. Pola asuh orang tua yang baik akan menghasilkan anak yang baik dan sebaliknya jika orang tua memberikan pola asuh kurang baik maka anak akan menjadi kurang baik. Berdasarkan hasil analisis ditemukan bahwa siswa yang mendapatkan pola asuh cenderung demokratis berjumlah 22 dengan presentase $61 \%$, sedangkan untuk siswa yang mendapatkan pola asuh cenderung otoriter berjumlah 11 siswa dengan presentase $31 \%$, dan siswa yang mendapatkan pola asuh cenderung permisif berjumlah 3 siswa dengan presentase $8 \%$. Untuk lebih detailnya maka akan dijelaskan sebagai berikut:

Pertama, Pola asuh cenderung demokratis banyak diterapkan oleh orang tua siswa kelas V SDN Jomblang 02 Semarang. Berdasarkan hasil penelitian peneliti mendapatkan 22 siswa memiliki pola asuh cenderung demokratis dengan presentase $61 \%$ didapatkan dari hasil angket yang telah diberikan secara online melalui google form. Pola asuh cenderung demokratis memiliki tiga indikator diantaranya memberikan kesempatan bagi anak untuk berpendapat dan bertindak, membimbing dan mengarahkan tanpa memaksa kehendak, serta memberikan penjelasan secara rasional jika pendapat anak tidak sesuai. Berdasarkan indikator pertama orang tua memberika kesempatan bagi anak untuk bertindak dan berpendapat, memberikan solusi jika anak kesulitan dalam belajar, orang tua membebaskan anak bermain tetapi dengan adanya aturan, orang tua dan anak saling bekerjasama supaya anak mendapat prestasi di sekolah, memberi teladan kepada anak supaya anak menjadi pribadi yang baik. Indikator kedua orang tua membimbimbing dan mengarahkan tanpa memaksa kehendak orang tua. Orang tua menasihati jika anak melakukan kesalahan, orang tua menasihati anak jika tidak mau belajar dan menemani anak saat belajar, membimbing anak agar patuh terhadap orang tua dan menjadi anak yang dewasa. Indikator ketiga orang tua harus memberi penjelasan secara rasional jika pendapat anak tidak sesuai ditunjukkan pada saat menasihati anak supaya tidak berburu-buru saat melakukan kegiatan. Hal ini diperkuat oleh hasil wawancara peneliti terhadap orang tua kelas $\mathrm{V}$ yang menerapkan pola asuh demokratis. Hasil dari pembahasan pola asuh orang tua tipe pola asuh demokratis merupakan tipe pola asuh yang terbaik dari semua tipe pola asuh yang ada (Jannah, 2012). Hal ini disebabkan tipe pola asuh ini selalu mendahulukan kepentingan bersama diatas kepentingan individu anak. Dalam proses pendidikan terhadap anak selalu bertitik tolak dari pendapat bahwa manusia adalah makhluk yang paling mulia di dunia. Orang tua selalu berusaha menyelaraskan kepentingan dan tujuan pribadi dengan kepentingan anak. orang tua senang menerima saran, pendapat, dan bahkan kritik dari anak. Mentolerir ketika anak membuat kesalahan dan memberikan pendidikan kepada anak agar jangan berbuat kesalahan dengan tidak mengurangi daya kreativitas anak. orang tua selalu berusaha untuk menjadikan anak lebih sukses dari dirinya. 
Kedua, Pola asuh cenderung otoriter diterapkan oleh 11 orang tua dengan presentase $31 \%$ yang didapatkan dari hasil angket yang dibagikan oleh peneliti secara online melalui google form. Pola asuh cenderung otoriter memiliki tiga indikator diantaranya, orang tua memberikan hukuman setiap anak melakukan pelanggaran, tidak memberikan kesempatan anak untuk bertindak dan berpendapat, dan orang tua memiliki peraturan yang ketat untuk anak. Berdasarkan indikator yang pertama orang tua memberikan hukuman setiap anak melakukan pelanggaran ditunjukan jika orang tua menghukum anak ketika anak tidak belajar atau main terus- menerus dan hukuman berupa hukum fisik supaya anak patuh sama orang tua. Indikator kedua yang diterapkan orang tua yaitu tidak memberikan kesempatan anak untuk bertindak dan berpendapat berupa anak tidak boleh keluar malam untuk belajar kelompok dan orang tua tidak menerima alasan anak jika anak melanggar peraturan. Indikator ketiga yang diterapkan orang tua memiliki peraturan yang ketat untuk anak seperti anak tidak boleh menonton pada malam hari, anak harus belajar setiap hari supaya mendapatkan prestasi. Hal ini diperkuat dengan adanya wawancara yang dilakukan terhadap peneliti kepada orang tua siswa kelas V. Pola asuh otoriter adalah tipe pola asuh yang memaksa kehendak (Apriastuti, 2013). Dengan tipe orang tua ini cenderung pengendali atau pengawas (contriller), selalu memaksa kehendak pada anak, tidak terbuka terhadap pendapat anak, sangat sulit menerima saran anak dan cenderung memaksakan kehendak dalam perbedaan, terlalu percaya diri sehingga menutup katup musyawarah. Kata-kata yang diucapkan orang tua adalah hukuman atau peraturan yang tidak dapat diubah, memonopoli tindak komunikasi dan seringkali meniadakan umpan balik dari anak.

Ketiga, Pola asuh cenderung permisif diterapkan oleh 3 orang tua siswa kelas V SDN Jomblang 02 Semarang. Berdasarkan hasil penelitian peneliti mendapatkan siswa memiliki pola asuh cenderung permisif dengan presentase $8 \%$ didapatkan dari hasil angket yang telah diberikan secara online melalui google form. Pola asuh cenderung demokratis memiliki tiga indikator diantaranya orang tua selalu menuruti kemauan anak baik positif maupun negatif, orang tua kurang mengendalikan anak, dan terlalu memberi kebebasan untuk anak tanpa ada batasan. Berdasarkan indikator indikator diantaranya orang tua selalu menuruti kemauan anak baik positif maupun negatif orang tua sering membelikan barang-barang yang anak suka tanpa memikirkan kedepannya, orang tua tidak pernah menasihati anak atau memarahi anak ketika anak melakukan kesalahan, dan orang tua selalu menuruti kemauan anak. Hal ini diperkuat dengan adanya wawancara terhadap orang tua siswa kelas V SD Negeri Jomblang 02 Semarang. Riski Juniarti et al. (2020) menyatakan bahwa pola pengasuhan permisif artinya pemanja anak, yaitu orang tua yang membebaskan anak untuk melakukan sesuatu sesuai kehendaknya sehingga pola asuh permisif kurang baik dalam membentuk karakter dan tanggung jawab anak selain itu juga menunjukkan prestasi yang kurang. Berdasarkan uraian diatas peneliti menemukan tiga pola asuh orang tua yang diterapkan di siswa kelas V SD Negeri Jomblang 02 Semarang yaitu pola asuh cenderung demokratis, pola asuh cenderung otoriter, dan pola asuh cenderung permisif. Setiap orang tua menerapkan pola asuh yang berbeda-beda terhadap anak dengan tujuan baik supaya anak menjadi baik dan mendapatkan prestasi di sekolah. Walaupun pola asuh orang tua yang diterapkan dapat mempengaruh mental, psikis, kreativitas dan prestasi anak tetap saja orang tua memiliki tujuan baik untuk anak di masa depan.

Jadi, dapat dikatakan bahwa pola asuh orang tua dapat mempengaruhi prestasi siswa walaupun semua kembali lagi ke pribadi masing-masing anak. Anak yang mendapatkan pola asuh cenderung demokratis mendapatkan prestasi yang sangat baik. Selain itu, pola asuh cenderung otoriter juga mendapatkan prestai Baik. Dengan demikian terdapat pola asuh orang tua yang mempengaruhi prestasi siswa kelas V SD Negeri Jomblang 02 Semarang. Maka pola asuh orang tua memiliki peran yang sangat penting untuk mendidik dan membimbing anak dalam meraih prestasi. Suasana dalam keluarga sangat berbengaruh untuk 
perkembangan anak, suasana keluarga yang harmonis maka akan menciptakan kepribadian anak yang baik dan sebaliknya suasana keluarga yang kurang baik maka akan menganggu tumbuh kembang anak. Karena keberhasilan anak tegantung dari orang tua yang mendidik, membimbimbing, menjaga dan mengasuh anak dengan baik sampai anak bisa mencapai keinginan berkat dorongan orang tua.

\section{Conclusion}

Berdasarkan hasil penelitian dan pembahasan yang telah di uraikan, maka peneliti menemukan tiga pola asuh orang tua yang sebelumnya ada empat pola asuh orang tua yang digunakan penelitian di kelas V SD Negeri Jomblang 02 Semarang. Fokus penelitian yaitu pola asuh cenderung demokratis, pola asuh cenderung otoriter, dan pola asuh cenderung permisif. Dari ketiga pola asuh tersebut pola asuh demokratis yang lebih banyak diterapkan oleh orang tua kelas V dengan jumlah 22 siswa, sedangkan pola asuh kedua yang banyak diterapkan oleh orang tua adalah pola asuh otoriter dengan jumlah 11 siswa, unruk pola asuh permisif diterapkan oleh orang tua dengan jumlah 3 siswa, dan peneliti tidak menemukan adanya pola asuh penelantaran. Terdapat pola asuh yang baik antara pola asuh orang tua dengan prestasi siswa, karena orang tua berusaha memberikan pola asuh yang baik kepada anak yang dapat membuat anak mempengaruhi prestasi anak yang baik di sekolah. Selain itu, ada beberapa faktor yang dapat mempengaruhi prestasi siswa seperti lingkungan sekolah, ruang lingkup kelas, dan intonasi guru saat menyampaikan materi kepada siswa. Orang tua memiliki berbagai pola asuh untuk mendidik, membimbing, dan menjaga anak. Pola asuh yang diterapkan orang tua akan mempengaruhi karakteritik anak dan prestasi anak pada kemudian hari.

\section{References}

Aminudin, B. (2016). Pengaruh Pola Asuh Otoritatif Terhadap Kecerdasan Interpersonal Siswa Kelas V SD. Jurnal Pendidikan Guru Sekolah Dasar, 25(5), 11, 26, 83. https://eprints.uny.ac.id/37886/ (Diakses 30 Januari 2019 Pukul 22:50 WIB)

Andriyani, P. I. (2013). Penerapan Model Pembelajaran Kooperatif Untuk Meningkatkan Pembelajaran Di Sd. Journal of Chemical Information and Modeling, 53(9), 1689-1699.

Apriastuti, D. A. (2013). Analisis Tingkat Pendidikan Dan Pola Asuh Orang Tua dengan Perkembangan Anak Usia 48 - 60 Bulan. Jurnal Ilmiah Kebidanan, 4(1), 1-14.

Dwi Wahyudi, A. (2016). Hubungan Pola Asuh Orang Tua Dengan Prestasi Belajar Pendidikan Jasmani Siswa Kelas Vi Sdn Kalipecabean Candi Sidoarjo. Jurnal Pendidikan Olahraga Dan Kesehatan, 3(2), 577-580.

Indrawati, F. (2015). Pengaruh Kemampuan Numerik dan Cara Belajar terhadap Prestasi Belajar Matematika. Formatif: Jurnal Ilmiah Pendidikan MIPA, 3(3), 215-223. https://doi.org/10.30998/formatif.v3i3.126

Jannah, H. (2012). Perilaku Moral Pada Anak Usia Di Kecamatan Ampek. Bentuk Pola Asuh Orang Tua Dalam Menanamkan Perilaku Moral Pada Anak Usia Di Kecamatan Ampek Angkek, 1, 257-258.

Mursidik, E. M., Samsiyah, N., \& Rudyanto, H. E. (2015). Creative Thinking Ability in Solving Open-Ended Mathematical Problems Viewed From the Level of Mathematics Ability of Elementary School Students. PEDAGOGIA: Journal of Education, 4(1), 23. www.journal.umsida.ac.id 
MUSTOFA, A. (2020). Kebiasaan Belajar Dan Berlatih Siswa Kelas Olahraga. Jurnal Pendidikan Olahraga Dan Kesehatan, 8(1), 151-155.

Pawestri, N. (2013). Tingkat Pendidikan Orang Tua Kaitannya Dengan Minat Dan Prestasi Belajar Siswa Di Sekolah Dasar. Journal of Chemical Information and Modeling, 53(9), 1689-1699.

Rabiatul, A. (2017). Pola Asuh Orang Tua dan Implikasinya Terhadap Pendidikan Anak. Jurnal Pendidikan Kewarganegaraan, 7(1), 33-48.

Rahmawati, F., Sudarma, I. K., \& Sulastri, M. (2014). Hubungan antara Pola Asuh Orang Tua dan Kebiasaan Belajar terhadap Prestasi Belajar Siswa SD Kelas IV Semester Genap di Kecamatan Melaya-Jembrana. Jurnal: MIimbarPGSD Undiksha, 2(1), 1-11.

Riski Juniarti1, N. K., Margunayasa, I. G., \& Kusmariyatni, N. (2020). Hubungan Antara Pola Asuh Orang Tua dan Konsep Diri dengan Kompetensi Pengetahuan Matematika Siswa. Jurnal Ilmiah Sekolah Dasar, 4(1), 17. https://doi.org/10.23887/jisd.v4i1.24273

Romdhani, A. (2016). Hubungan Bimbingan Keluarga dengan Prestasi Belajar Ips Siswa. X, $1-21$.

Shaleh, M. (2016). Pengaruh Motivasi, Faktor Keluarga, Lingkungan Kampus Dan Aktif Berorganisasi Terhadap Prestasi Akademik. Phenomenon: Jurnal Pendidikan MIPA, 4(2), 109. https://doi.org/10.21580/phen.2014.4.2.122

Sjukur, S. B. (2013). Pengaruh blended learning terhadap motivasi belajar dan hasil belajar siswa di tingkat SMK. Jurnal Pendidikan Vokasi, 2(3), 368-378. https://doi.org/10.21831/jpv.v2i3.1043

Soraya, A. N., \& Khafid, M. (2016). Pengaruh Kualitas Pola Asuh Orang Tua, Cara Belajar Dan Peran Kelompok Teman Sebaya Terhadap Prestasi Belajar Mata Pelajaran Ekonomi. Economic Education Analysis Journal, 5(2), 560-560. https://journal.unnes.ac.id/sju/index.php/eeaj/article/view/13661

Syah, M. (2011). Psikologi Pendidikan. PT Remaja Rosdakarya.

U.S., S. (2012). Peran Berpikir Kreatif Dalam Proses Pembelajaran Matematika Supardi. 2(3), 248-262.

Vidya, H., \& Mustikasari, S. (2018). Hubungan Pola Asuh Orangtua Dengan Kemandirian Personal Hygiene Anak Usia Prasekolah Di Tkit Permata Mulia Desa Banjaragung Kecamatan Puri Kabupaten Mojokerto. Nurse and Health: Jurnal Keperawatan ORIGINAL, 7(1), 51-60. https://doi.org/https://doi.org/10.36720/nhjk.v7il.33

Wahid, F. S., Setiyoko, D. T., Riono, S. B., \& Saputra, A. A. (2020). Pengaruh Lingkungan Keluarga Dan Lingkungan Sekolah Terhadap Prestasi Belajar Siswa. Syntax Literate; Jurnal Ilmiah Indonesia, 5(8), 555. https://doi.org/10.36418/syntax-literate.v5i8.1526 